Article

\title{
Quorum Sensing in Some Representative Species of Halomonadaceae
}

Ali Tahrioui ${ }^{1}$, Melanie Schwab ${ }^{1}$, Emilia Quesada ${ }^{1,2}$ and Inmaculada Llamas ${ }^{1,2, *}$

1 Department of Microbiology, Faculty of Pharmacy, University of Granada, Campus Universitario de Cartuja, 18071 Granada, Spain; E-Mails: atahrioui@ugr.es (A.T.); melanieschwab@gmx.ch (M.S.); equesada@ugr.es (E.Q.)

2 Biotechnology Research Institute, Polígono Universitario de Fuentenueva, University of Granada, 18071 Granada, Spain

* Author to whom correspondence should be addressed; E-Mail: illamas@ugr.es;

Tel.: +34-958-243871; Fax: +34-958-246235.

Received: 7 December 2012; in revised form: 18 January 2013 / Accepted: 22 February 2013 /

Published: 5 March 2013

\begin{abstract}
Cell-to-cell communication, or quorum-sensing (QS), systems are employed by bacteria for promoting collective behaviour within a population. An analysis to detect QS signal molecules in 43 species of the Halomonadaceae family revealed that they produced $N$-acyl homoserine lactones (AHLs), which suggests that the QS system is widespread throughout this group of bacteria. Thin-layer chromatography (TLC) analysis of crude AHL extracts, using Agrobacterium tumefaciens NTL4 (pZLR4) as biosensor strain, resulted in different profiles, which were not related to the various habitats of the species in question. To confirm AHL production in the Halomonadaceae species, PCR and DNA sequencing approaches were used to study the distribution of the luxI-type synthase gene. Phylogenetic analysis using sequence data revealed that 29 of the species studied contained a LuxI homolog. Phylogenetic analysis showed that sequences from Halomonadaceae species grouped together and were distinct from other members of the Gammaproteobacteria and also from species belonging to the Alphaproteobacteria and Betaproteobacteria.
\end{abstract}

Keywords: hypersaline environments; halophiles; quorum sensing; $N$-acyl homoserine lactones; Halomonadaceae 


\section{Introduction}

The definition of extreme environments has been the subject of considerable controversy and as yet, due to its complexity, no consensus of opinion has been reached. In 1979 Brock defined extreme environments as those habitats with low species diversity [1]. It has been suggested, for example, that in hypersaline environments, a typical extreme habitat, environmental factors such as a high salt concentration along with low oxygen concentrations, high or low temperatures, basic $\mathrm{pH}$ and solar radiation may contribute to limiting their biodiversity [2]. Nevertheless, the results of a large number of ecological studies conducted recently in extreme environments indicate that in fact they contain a fairly high diversity of species [3-6].

According to $16 \mathrm{~S}$ rDNA gene-sequence analysis, the family Halomonadaceae [7], within the order Oceanospirillales, forms a separate phylogenetic lineage within the class Gammaproteobacteria. Halomonadaceae contains the largest number of halophilic species described to date [8], including 10 genera of halophilic and halotolerant bacteria [9]: Aidingimonas (one species), Carnimonas (one species), Chromohalobacter (nine species), Cobetia (two species), Halomonas (80 species), Kushneria (five species), Modicisalibacter (one species) and Salinicola (three species); as well as two genera of non-halophilic bacteria: Halotalea (one species) and Zymobacter (one species). Many members of the Halomonadaceae family are moderately halophilic since they grow best in media containing from $0.5 \mathrm{M}$ to $2.5 \mathrm{M} \mathrm{NaCl}$ [10], although some can grow over a very broad range of salt concentrations due to their ability to accumulate organic compounds to adapt themselves to changes in environmental osmolarity. Compatible solutes such as betaine can be taken up from the external medium or others, such as ectoine, synthesized by the cells themselves [8,11,12]. Halomonadaceae species have been isolated from very different habitats, including the sea, salterns, saline soils and endorheic lakes, and have also been found in some seafoods, marine invertebrates and even in a mural painting $[9,13]$.

Extensive studies carried out over the last 30 years into this group of halophiles have led us to a better understanding of their biodiversity, phylogenetic relationships, physiological and haloadaptative mechanisms and, more recently, their biotechnological applications. Some moderate halophiles are recognised for their potential use in biotechnology because of their capacity to produce exopolysaccharides, enzymes and compatible solutes such as ectoine-used as a stabilizer for enzymes - as well as for their active role in the process of denitrification and the degradation of aromatic compounds $[6,13,14]$.

Within the Halomonadaceae, Halomonas is one of the genera most frequently isolated from hypersaline waters and soils by conventional-culture techniques [11,15]. Molecular-ecology techniques based on 16S rDNA sequence analysis suggest that Halomonas ventosae is the predominant species in these habitats [16]. Nevertheless, the ecological role that Halomonas species play in these habitats and their relationships with other halophilic and non-halophilic microorganisms are still unknown.

Bacteria have evolved sophisticated mechanisms to co-ordinate gene expression, such as quorum sensing (QS) [17-19], which involves the production of signal molecules known as autoinducers. Autoinducers include, among others, $N$-acyl homoserine lactones (AHLs), produced by the Proteobacteria, oligopeptides, produced by the Firmicutes, and furanosylborate diester (AI-2), which is produced by both Proteobacteria and Firmicutes and used for interspecies communication [20,21]. The classical AHL-based systems contain a luxI homologue gene, which is responsible for the 
synthesis of AHLs, and a luxR homologue gene, which is an AHL-dependent transcriptional regulator. AHL-based systems involve the accumulation of AHL molecules in the extracellular medium until a critical concentration is reached, at which point the AHLs bind a transcriptional activator, which triggers the expression of target genes, including the luxI gene, leading in turn to the production of more AHLs [22-24] and the expression of virulence factors and exoenzymes, conjugal DNA transfer, control of plasmid-copy number, production of and susceptibility to antibiotics, biofilm formation and exopolysaccharide production [20,21].

AHL-dependent systems have been reported in many genera belonging to the phylum Proteobacteria. In addition, studies based on genome sequencing have revealed that many bacteria contain possible luxI/luxR homologues and, in some cases, multiple coexisting QS systems [25]. Nevertheless, little is known about the QS systems in halophilic microorganisms. In our experiments we have found that four exopolysaccharide-producing species of the genus Halomonas produce AHL-autoinducer molecules [26]. We have also described the structure of AHL molecules produced by Halomonas anticariensis ( $\mathrm{C}_{4}-\mathrm{HSL}, \mathrm{C}_{6}$-HSL, $\mathrm{C}_{8}$-HSL and $\mathrm{C}_{12}$-HSL) [26] and identified and characterized the QS genes hanR/hanI involved in their production [27]. In addition, we have proved that the QS system is regulated by a GacS/GacA two-component system, suggesting its integral involvement in the intercellular communication strategies of this bacterium [28].

In this present study we have detected and identified quorum-sensing systems that rely upon the production of AHLs in 43 species belonging to the Halomonadaceae family. Using PCR and DNA sequencing approaches, we have studied the distribution of the LuxI-type synthase in 29 of these species and constructed a phylogenetic tree, that was based on a partial sequence of this protein.

\section{Results and Discussion}

\subsection{Detection of AHLs in the Halomonadaceae Family}

We have investigated the existence of AHL-dependent QS systems in 43 species of the Halomonadaceae family. These 43 bacteria, the type strains of their respective species, were isolated from very different saline habitats, including salterns, saline soils, marshes and seawater, among others (Table 1). They include 12 species discovered by our research group during the course of ecological and taxonomic studies conducted in hypersaline environments in Spain, Chile and Morocco [29-41]. The strains used in this study include representatives of the following genera: Chromohalobacter (one species), Cobetia (one species), Halomonas (33 species), Halotalea (one species), Kushneria (three species), Modicisalibacter (one species) and Salinicola (two species). So far AHL signal molecules have only been detected in four exopolysaccharide-producing species of Halomonas described in our laboratory: H. eurihalina, H. maura, H. ventosae and H. anticariensis [26].

To overcome the limitation of the "cross-streak" method [42], in which each couple of sensor test strains must be cultured under optimum conditions without interfering with each other, we extracted AHLs from all the strains assayed and added them to agar plates upon which the biosensor strain had already been spread (see Experimental Section). Our choice of biosensor strains was ultimately based on previous experience in our laboratory [26]. Thus we chose the Chromobacterium violaceum strain CV026, a mutant which cannot synthesize its own quorum-sensing signal molecules and responds to 
exogenously added short-chain AHLs $\left(\mathrm{C}_{4}-\mathrm{C}_{6}\right.$-HSLs), producing a pigment called violacein [43], and also Agrobacterium tumefaciens NTL4 (pZLR4), a sensitive, broad-spectrum AHL-responsive reporter that is unable to produce its own AHLs and contains a lacZ fusion to the quorum-sensing regulated gene traG. This latter strain is sensitive to AHLs with medium-to-long acyl chains that, when added exogenously, activate lacZ fusion, which is detectable by the appearance of a blue stain in the presence of X-Gal [44]. All the strains tested synthesized signal molecules to activate the biosensor A. tumefaciens NTL4 (pZLR4) (see Figure 1 for some examples). No signal was detected when a sample from an uninoculated cultured medium of MY 7.5\% (w/v) was tested as negative control (data not shown). These results initially suggested that most strains were able to produce AHLs and therefore probably possess at least one AHL-QS system. Nevertheless, only Halomonas rifensis $\mathrm{HK} 31^{\mathrm{T}}$ and H. anticariensis FP35 ${ }^{\mathrm{T}}$, used as control, produced AHLs in sufficient quantities to activate C. violaceum $\mathrm{CV} 026$ under our assay conditions. As is demonstrated below, these two strains produce about five times more AHL than the rest of the species tested (Figure 2). We have in fact already described how some species of Halomonas, such as H. anticariensis FP35 ${ }^{\mathrm{T}}$, synthesize much greater quantities of AHLs than others, such as H. eurihalina, H. maura and H. ventosae [26].

Figure 1. $N$-acyl homoserine lactone (AHL) production by Halomonas salina $\mathrm{F} 8-11^{\mathrm{T}}$, H. eurihalina F9-6 ${ }^{\mathrm{T}}$, H. pacifica DSM $4742^{\mathrm{T}}$ and H. variabilis DSM $3051^{\mathrm{T}}$. A volume of $5 \mu \mathrm{L}$ of AHLs previously extracted from the bacterial cultures were visualized on agar plate diffusion assay by means of the indicator strain A. tumefaciens NTL4 (pZLR4).

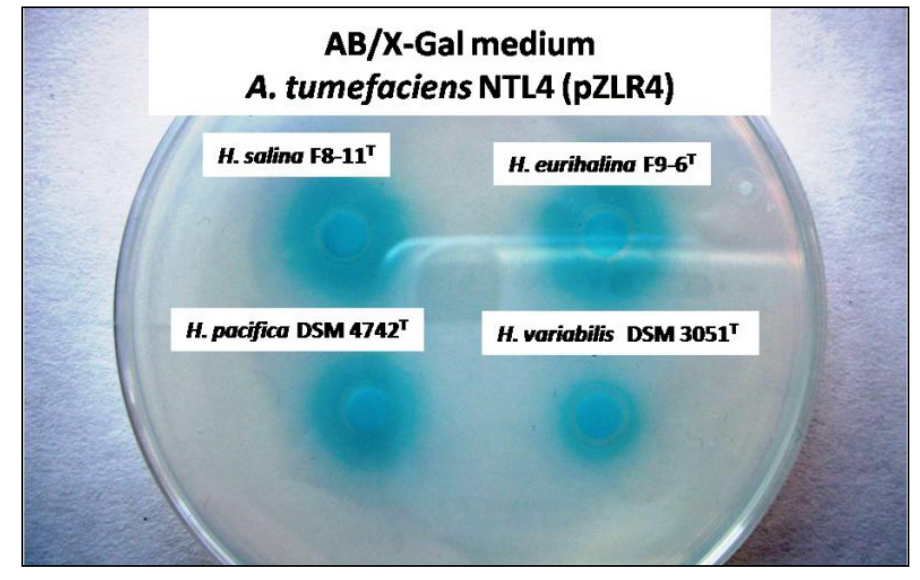

\subsection{Characterization of the AHLs}

The use of the indicator organisms in combination with thin-layer chromatography (TLC) provides a simple, rapid way of determining the number and nature of the AHLs produced by a particular strain [44]. We analysed the culture extracts of the 43 Halomonadaceae strains (Table 1) using TLC in combination with the biosensor A. tumefaciens NTL4 (pZLR4). This analysis showed the production of different AHL profiles amongst the various genera e.g. Chromohalobacter salexigens (Figure 2, lane 2), Cobetia marina (Figure 2, lane 3), Halomonas anticariensis (Figure 2, lane 6), Halotalea alkalilenta (Figure 2, lane 37), Kushneria marisflavi (Figure 2, lane 40) and Salinicola halophilus (Figure 2, lane 42) and also among certain species such as Halomonas alimentariaYKJ-16 ${ }^{\mathrm{T}}$ (Figure 2, lane 4), H. anticariensis $\mathrm{FP}^{\mathrm{T}} 5^{\mathrm{T}}$ (Figure 2, lane 6), H. desiderata $\mathrm{FB} 2^{\mathrm{T}}$ (Figure 2, lane 11) and 
H. eurihalina F9-6 ${ }^{\mathrm{T}}$ (Figure 2, lane 14). Similarly, in a previous study [26] we found that strains belonging to the same species showed the same AHL profiles whilst different species showed different profiles. In just the same way, significant differences have been identified in the AHL profiles of the marine species Vibrio salmonicida [45] and $V$. anguillarum [46].

Figure 2. Thin-layer chromatography (TLC) analysis of the AHLs produced by the 43 species of Halomonadaceae: lane 1, Carnimonas nigrificans $\mathrm{CTCBS1}^{\mathrm{T}}$, lane 2, Chromohalobacter salexigens DSM3043 ${ }^{\mathrm{T}}$; lane 3, Cobetia marina $219^{\mathrm{T}}$; lane 4, Halomonas alimentaria $\mathrm{YKJ}-16^{\mathrm{T}}$; lane 5, H. almeriensis $\mathrm{M} 8^{\mathrm{T}}$; lane $6, H$. anticariensis $\mathrm{FP} 35^{\mathrm{T}}$; lane 7 , H. aquamarina $558^{\mathrm{T}}$; lane $8, H$. campaniensis $5 \mathrm{AG}^{\mathrm{T}}$; lane $9, H$. cerina $\mathrm{SP}^{\mathrm{T}}$; lane 10 , H. denitrificans $\mathrm{M}^{2} 9^{\mathrm{T}}$; lane $11, H$. desiderata $\mathrm{FB} 2^{\mathrm{T}}$; lane $12, H$. elongata $1 \mathrm{H}^{\mathrm{T}}$; lane 13 , H. eurihalina $\mathrm{F} 9-6^{\mathrm{T}}$, lane $14, H$. fontilapidosi $5 \mathrm{CR}^{\mathrm{T}}$, lane $15, H$. gudaonensis SL014B-69 ${ }^{\mathrm{T}}$; lane 16, H. halmophila ACAM 71 ${ }^{\mathrm{T}}$; lane 17, H. halodenitrificans ATCC $13511^{\mathrm{T}}$; lane 18, H. halodurans DSM 5160 ${ }^{\mathrm{T}}$; lane 19, H. koreensis SS20 ${ }^{\mathrm{T}}$; lane 20, H. magadiensis $21 \mathrm{MI}^{\mathrm{T}}$; lane 21, H. maura S-31 ${ }^{\mathrm{T}}$; lane 22, H. meridiana ACAM $246^{\mathrm{T}}$; lane $23, H$. mongoliensis Z-7009 ${ }^{\mathrm{T}}$; lane 24, H. nitroreducens $11-\mathrm{S}^{\mathrm{T}}$; lane $25, H$. organivorans $\mathrm{G}-16.1^{\mathrm{T}}$; lane $26, H$. pacifica DSM $4742^{\mathrm{T}}$; lane $27, H$. pantelleriensis $\mathrm{AAP}^{\mathrm{T}}$; lane $28, H$. ramblicola $\mathrm{RS}-16^{\mathrm{T}}$; lane 29, H. rifensis $\mathrm{HK} 31^{\mathrm{T}}$; lane $30, H$. saccharevitans $\mathrm{AJ} 275^{\mathrm{T}}$; lane $31, H$. salina $\mathrm{F} 8-11^{\mathrm{T}}$; lane 32 , H. shengliensis $\mathrm{SL} 014 \mathrm{~B}-85^{\mathrm{T}}$; lane $33, H$. stenophila $\mathrm{N} 12^{\mathrm{T}}$; lane $34, H$. subglaciescola ACAM $12^{\mathrm{T}}$; lane $35, H$. variabilis DSM $3051^{\mathrm{T}}$; lane $36, H$. ventosae $\mathrm{Al}-12^{\mathrm{T}}$, lane 37 , Halotalea alkalilenta $\mathrm{AW}-7^{\mathrm{T}}$; lane 38, Kushneria avicenniae $\mathrm{MW}^{2} \mathrm{a}^{\mathrm{T}}$; lane 39 , K. indalinina CG2.1 ${ }^{\mathrm{T}}$; lane 40, K. marisflavi SW32 ${ }^{\mathrm{T}}$; lane 41, Modicisalibacter tunisiensis LIT2 $^{\mathrm{T}}$; lane 42, Salinicola halophilus CG4.1 ${ }^{\mathrm{T}}$; lane 43, S. salarius $\mathrm{M}^{\mathrm{T}}{ }^{\mathrm{T}}$. Each lane contains $10 \mu \mathrm{L}$ of AHL crude extract except for lanes 6 and 29, which contain $5 \mu \mathrm{L}$. Lane S; synthetic AHL standards: oxo- $\mathrm{C}_{6}$-HSL (4.7 pmol), $\mathrm{C}_{6}$-HSL (804 pmol), $\mathrm{C}_{8}$-HSL (31.6 pmol), $\mathrm{C}_{10}$-HSL (2 nmol), $\mathrm{C}_{12}$-HSL (4.8 nmol).

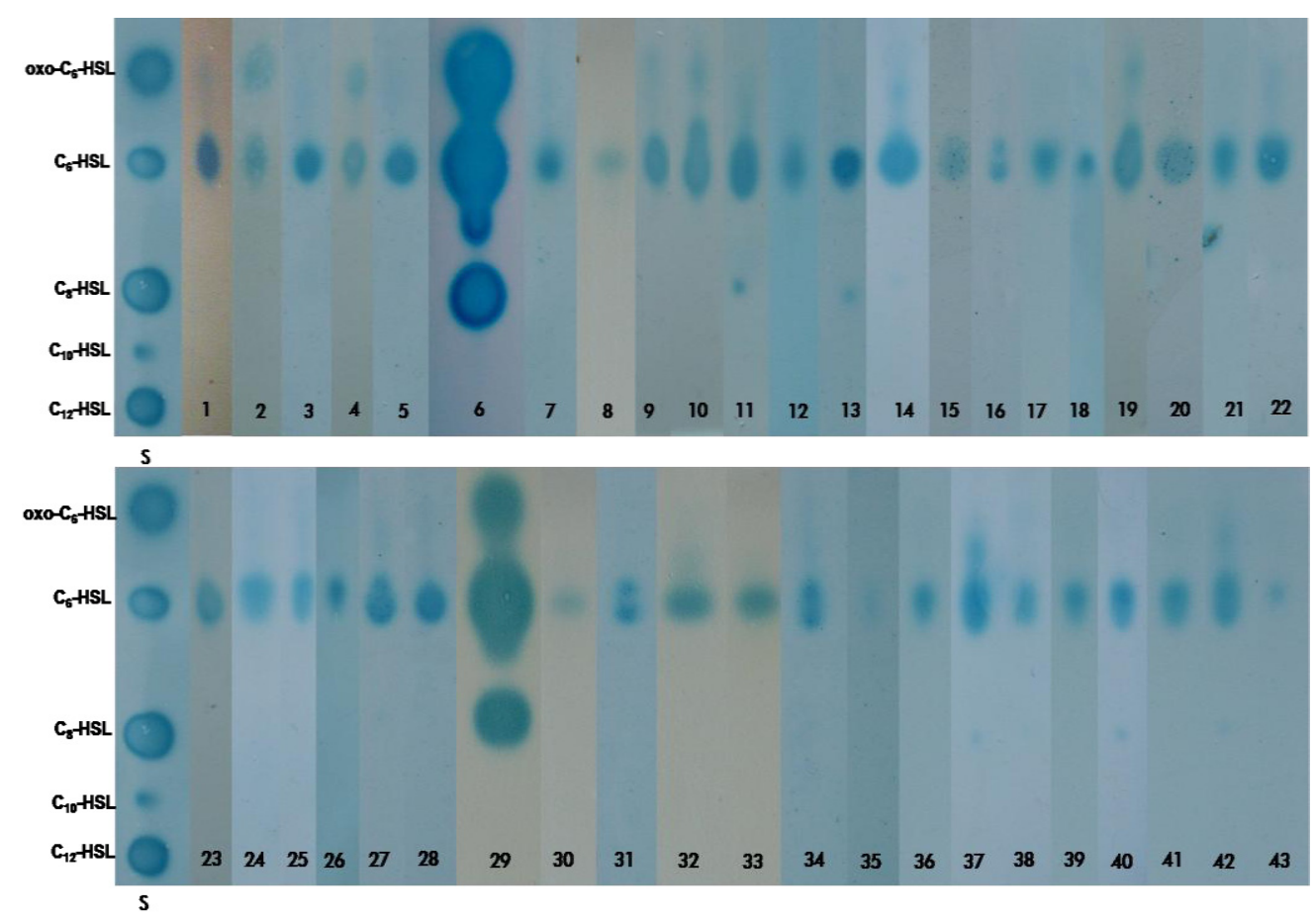


The AHL patterns from Halomonadaceae species contain from one to three spots with mobilities similar to those of the $\mathrm{C}_{8}$-HSL, $\mathrm{C}_{6}$-HSL and 3-oxo- $\mathrm{C}_{6}$-HSL standards. Differences were also observed in the quantities of AHLs synthesized, Halomonas anticariensis $\mathrm{FP} 35^{\mathrm{T}}$ and Halomonas rifensis $\mathrm{HK} 31^{\mathrm{T}}$ synthesizing about five times more AHLs than any of the other 41 species examined (Figure 2. lanes 6 and 29). Halomonas variabilis DSM $3051^{\mathrm{T}}$ (Figure 2, lane 35) and Salinicola salarius $\mathrm{M} 27^{\mathrm{T}}$ (Figure 2, lane 43) produce as low an amount of signal as that from the uninoculated cultured medium MY 7.5\% (w/v) [26], although, their AHL-extracts did activate the A. tumefaciens NTL4 (pZLR4) indicator strain when the diffusion plate assay was carried out (data not shown). The most predominant AHL molecule was $\mathrm{C}_{6}$-HSL. In $H$. anticariensis $\mathrm{FP} 35^{\mathrm{T}}$ this $\mathrm{AHL}$ had been previously identified by gas chromatography/mass spectrometry (GM/MS) and electrospray ionization tandem mass spectrometry (ESI MS/MS) [26], suggesting that this signal molecule may well be biologically active in intercellular communication strategies within the Halomonadaceae family. The synthesis of short-chain-acyl AHLs, such as $\mathrm{C}_{6}$-HSL and $\mathrm{C}_{8}$-HSL, is also very common among the species belonging to the Vibrionaceae family, which are ubiquitous in marine environments $[45,46]$.

\subsection{Distribution of the Autoinducer Synthase Gene}

The luxI autoinducer synthase gene has been reported to be responsible for AHL production [18,47]. Therefore we tested its presence in the genome of 43 Halomonadaceae species, using luxI primers to amplify by PCR a fragment (300-400 bp) which forms part of the active site of the enzyme [48]. In this way we identified them in 29 species. On sequencing they turned out to be homologous to a luxI gene fragment. We did not, however, detect PCR fragments in the other 14 AHL-producing strains, possibly due to primer mismatching. In the cases of Chromohalobacter salexigens and Halomonas elongata, both of which do produce AHLs and the sequenced genomes of which are available, no luxI gene could be identified, due probably to their having different AHL synthases, either belonging to the LuxM protein family found in the genus Vibrio [49,50] or to the HdtS protein family identified in Pseudomonas fluorescens [51].

To carry out a phylogenetic analysis of the LuxI synthase in the 29 positive species of the Halomonadaceae family we conducted a multiple sequence alignment, including amino-acid sequences of LuxI synthase that had been experimentally determined in other members of the phyla Alphaproteobacteria, Betaproteobacteria and Gammaproteobacteria. The phylogenetic tree constructed according to the neighbour-joining method showed that all the amino-acid sequences from the Halomonadaceae family grouped together and were distinct from the rest of the Gammaproteobacteria analysed, and also from the species belonging to the Alphaproteobacteria and Betaproteobacteria (Figure 3a). The clustering of the 29 Halomonadaceae in which the luxI fragment was detected was not related to the habitat from which they were isolated (Table 1). The distribution of the Halomonadaceae family with respect to the rest of species analysed in the phylogenetic tree based on the 16S rDNA sequences (Figure 3b) was similar to that obtained from the LuxI sequence (Figure 3a). This result indicates that the LuxI amino-acid partial region used in this study is conserved among the family Halomonadaceae members. 
Figure 3. Phylogenetic trees based on LuxI sequences (a) and 16S rDNA sequences (b) found in some members of Alphaproteobacteria, Betaproteobacteria and Gammaproteobacteria, including the species studied here belonging to the Halomonadaceae family. Abbreviations for bacterial genus names: A, Aliivibrio; Ac, Acidithiobacillus; Ae, Aeromonas; Ag, Agrobacterium; Az, Azospirillium; B, Burkholderia; Car, Carnimonas; C, Chromobacterium; Er, Erwinia; En, Enterobacter; H, Halomonas; Halot, Halotalea; K, Kushneria; M, Modicisalibacter; Me, Mesorhizobium; Ps, Pseudomonas; Rh, Rhizobium; Ra, Ralstonia; Rho, Rhodobacter; Si, Sinorhizobium; S, Salinicola; Se, Serratia; V, Vibrio; $Y$, Yersinia. The scale bar indicates the mean number of substitutions per site. Bootstrap values were obtained from 1,000 replicates via neighbour-joining algorithms using the MEGA program. Only branches with values $>50 \%$ are shown. The branches highlighted in red are sequences from Alphaproteobacteria, in green from Betaproteobacteria and in blue from Gammaproteobacteria. The sequence accession numbers are given in brackets.

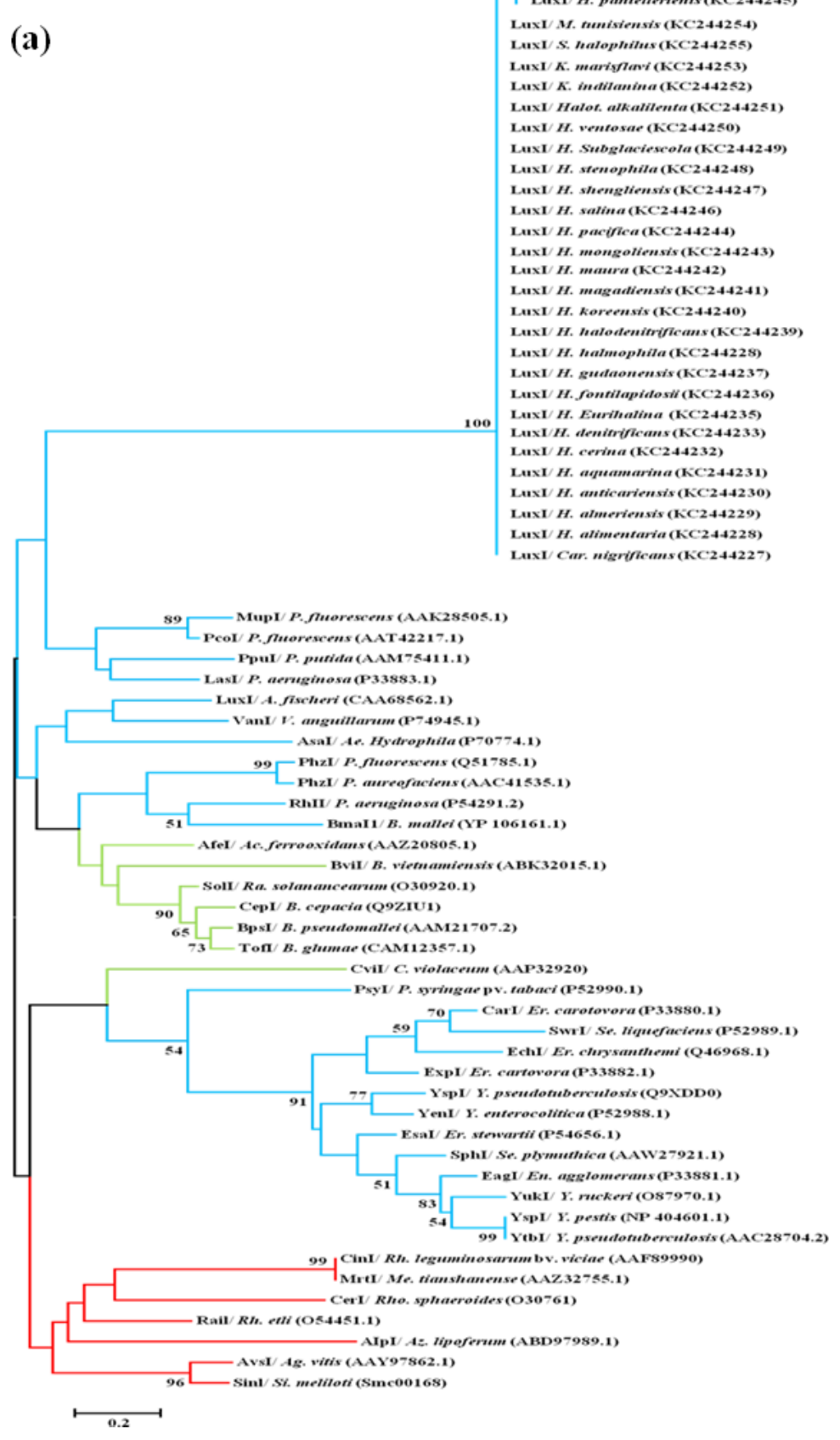


Figure 3. Cont.

(b)
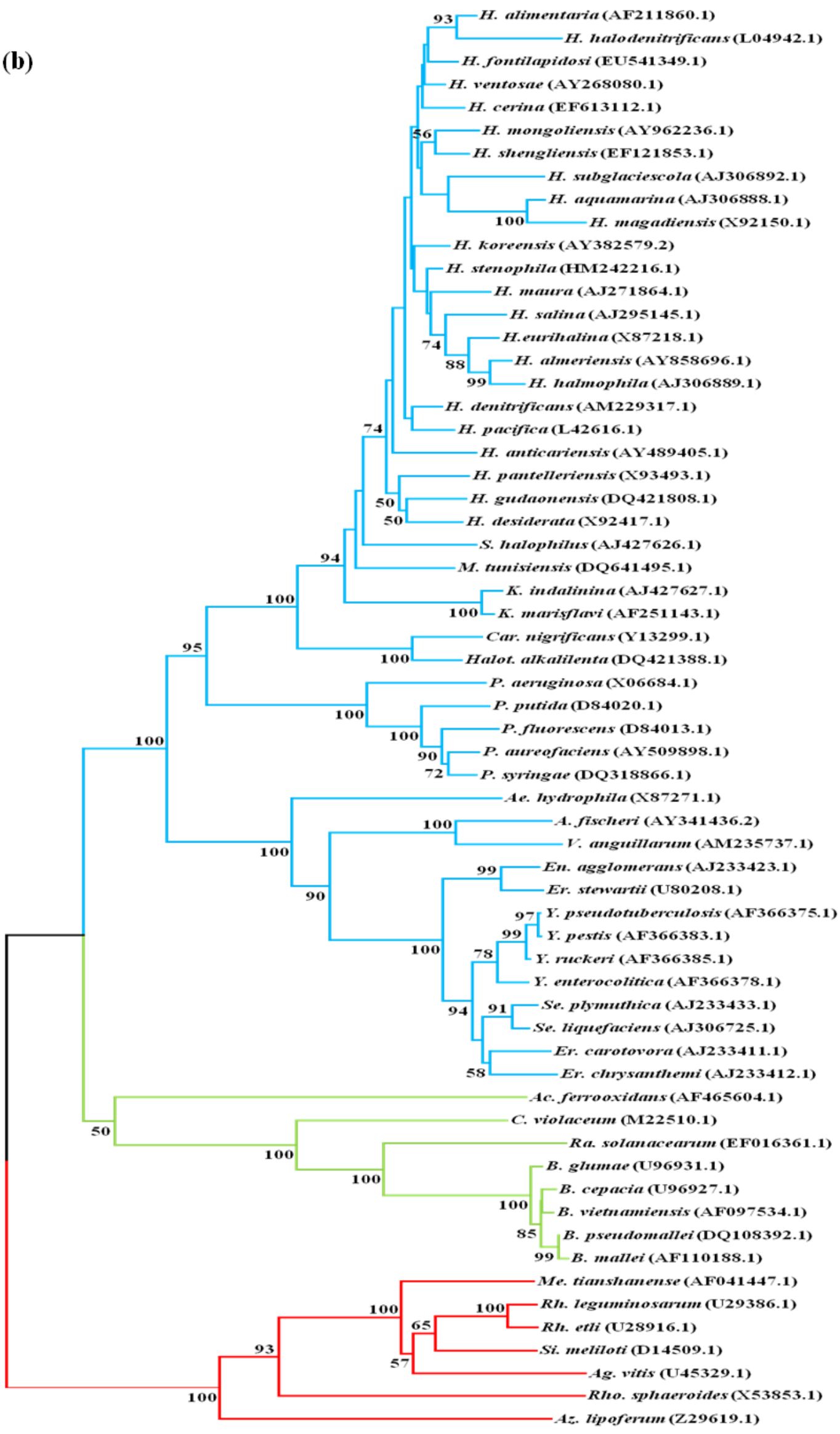


\section{Experimental Section}

Bacterial strains. We used the type strains of 43 species belonging to the Halomonadaceae family (Table 1). Strains were cultured at $32{ }^{\circ} \mathrm{C}$ in MY medium (3 g malt extract, $3 \mathrm{~g}$ yeast extract, $10 \mathrm{~g}$ glucose and $5 \mathrm{~g}$ peptone per litre) [52,53] modified with a balanced mixture of sea salts [54].

Table 1. Species of the Halomonadaceae family included in this study [9].

\begin{tabular}{|c|c|c|}
\hline Species & Strain & Ecological Niches \\
\hline 1. Carnimonas nigrificans & $\mathrm{CTCBS}^{\mathrm{T}}$ & Cured meat, Spain \\
\hline 2. Chromohalobacter salexigens & DSM $3043^{\mathrm{T}}$ & Solar saltern, Netherlands \\
\hline 3. Cobetia marina & $219^{\mathrm{T}}$ & Sea water, USA \\
\hline 4. Halomonas alimentaria & YKJ-16 $6^{\mathrm{T}}$ & $\begin{array}{l}\text { Jeotgal, a traditional Korean fermented seafood, } \\
\text { Korea }\end{array}$ \\
\hline 5. H. almeriensis & $M 8^{\mathrm{T}}$ & Solar saltern, south-east Spain \\
\hline 6. H. anticariensis & $\mathrm{FP} 35^{\mathrm{T}}$ & Saline wetland, southern Spain \\
\hline 7. H. aquamarina & $558^{\mathrm{T}}$ & Pacific ocean \\
\hline 8. H. campaniensis & $5 \mathrm{AG}^{\mathrm{T}}$ & Mineral pool, Italy \\
\hline 9. H. cerina & $\mathrm{SP} 4^{\mathrm{T}}$ & Saline soil, Spain \\
\hline 10. H. denitrificans & $\mathrm{M} 29^{\mathrm{T}}$ & Saline water, Korea \\
\hline 11. H. desiderata & $\mathrm{FB} 2^{\mathrm{T}}$ & Municipal sewage works, Germany \\
\hline 12. H. elongata & $1 \mathrm{H} 9^{\mathrm{T}}$ & Solar saltern, Netherlands \\
\hline 13. H. eurihalina & F9- $6^{\mathrm{T}}$ & Saline soil, Spain \\
\hline 14. H. fontilapidosi & $\mathrm{CR}-5^{\mathrm{T}}$ & Saline soil, southern Spain \\
\hline 15. H. gudaonensis & SL014B-69 ${ }^{\mathrm{T}}$ & Saline soil contaminated by crude oil, China \\
\hline 16. H. halmophila & $\operatorname{ACAM} 71^{\mathrm{T}}$ & Dead Sea, Israel \\
\hline 17. H. halodenitrificans & ATCC $13511^{\mathrm{T}}$ & Meat in brine \\
\hline 18. H. halodurans & DSM $5160^{\mathrm{T}}$ & Great Bay estuary, USA \\
\hline 19. H. koreensis & $\mathrm{SS} 20^{\mathrm{T}}$ & Solar saltern, Korea \\
\hline 20. H. magadiensis & $21 \mathrm{MI}^{\mathrm{T}}$ & Soda lake, East-African Rift Valley \\
\hline 21. H. maura & $\mathrm{S}-31^{\mathrm{T}}$ & Saltern, Morocco \\
\hline 22. H. meridiana & ACAM $246^{\mathrm{T}}$ & Saline lake, Antarctic \\
\hline 23. H. mongoliensis & $Z-7009^{\mathrm{T}}$ & Soda lake, Mongolia \\
\hline 24. H. nitroreducens & $11-S^{\mathrm{T}}$ & Solar saltern, Chile \\
\hline 25. H. organivorans & G-16.1 ${ }^{\mathrm{T}}$ & $\begin{array}{l}\text { Hypersaline habitats contaminated by aromatic } \\
\text { organic compounds, southern Spain }\end{array}$ \\
\hline 26. H. pacifica & $\operatorname{DSM} 4742^{\mathrm{T}}$ & Pacific ocean \\
\hline 27. H. pantelleriensis & $\mathrm{AAP}^{\mathrm{T}}$ & Hard lake sand, Pantelleria island, Italy \\
\hline 28. H. ramblicola & RS- $16^{\mathrm{T}}$ & Saline soil, south-east Spain \\
\hline 29. H. rifensis & $\mathrm{HK}-31^{\mathrm{T}}$ & Solar saltern, Morocco \\
\hline 30. H. saccharevitans & $\mathrm{AJ} 275^{\mathrm{T}}$ & Salt lake and a subterranean saline well, China \\
\hline 31. H. salina & $\mathrm{F} 8-11^{\mathrm{T}}$ & Saline soil, Spain \\
\hline 32. H. shengliensis & SLO14B-85 & Saline soil contaminated with crude oil, China \\
\hline 33. H. stenophila & $\mathrm{N} 12^{\mathrm{T}}$ & Saline soil, Spain \\
\hline 34. H. subglaciescola & $\operatorname{ACAM} 12^{\mathrm{T}}$ & Antarctic hypersaline, meromictic lake \\
\hline 35. H. variabilis & $\operatorname{DSM} 3051^{\mathrm{T}}$ & Great Salt Lake, USA \\
\hline
\end{tabular}


Table 1. Cont.

\begin{tabular}{lll}
\hline \multicolumn{1}{c}{ Species } & \multicolumn{1}{c}{ Strain } & \multicolumn{1}{c}{ Ecological Niches } \\
\hline 36. H. ventosae & $\mathrm{Al}-12^{\mathrm{T}}$ & Saline soil, south-eastern Spain \\
37. Halotalea alkalilenta & $\mathrm{AW}-7^{\mathrm{T}}$ & Alkaline olive-mill waste (alpechin), Greece \\
38. Kushneria avicenniae & $\mathrm{MW} 2 \mathrm{a}^{\mathrm{T}}$ & $\begin{array}{l}\text { Salty leaves of Avicennia germnans trees } \\
\text { growing near solar salterns, Puerto Rico }\end{array}$ \\
& & Solar saltern, south-east Spain \\
39. K. indalinina & $\mathrm{CG} 2.1^{\mathrm{T}}$ & Water from the Yellow Sea, Korea \\
40. K. marisflavi & $\mathrm{SW} 32^{\mathrm{T}}$ & Oilfield-water injection sample, southern \\
41. Modicisalibacter tunisiensis & $\mathrm{LIT} 2^{\mathrm{T}}$ & Tunisia \\
& & Solar saltern, south-east Spain \\
42. Salinicola halophilus & $\mathrm{CG} 4.1^{\mathrm{T}}$ & Saline water, Korea \\
43. S. salarius & $\mathrm{M} 27^{\mathrm{T}}$ & \\
\hline
\end{tabular}

Note: Species shaded in grey indicates that the LuxI homolog has been detected by PCR.

Chromobacterium violaceum CV026 was cultured at $30{ }^{\circ} \mathrm{C}$ in LB medium supplemented with $2.5 \mathrm{mM}$ $\mathrm{CaCl}_{2}$ and $2.5 \mathrm{mM} \mathrm{MgSO}{ }_{4}(\mathrm{LB} / \mathrm{MC})$ and containing $50 \mu \mathrm{g}$ kanamycin per $\mathrm{mL}$ [43]. Agrobacterium tumefaciens NTL4 (pZLR4) was cultured at $30{ }^{\circ} \mathrm{C}$ in LB medium supplemented with $2.5 \mathrm{mM} \mathrm{CaCl}_{2}$ and $2.5 \mathrm{mM} \mathrm{MgSO}$ (LB/MC), in MGM minimal medium (11 g Na $2 \mathrm{HPO}_{4}, 3 \mathrm{~g} \mathrm{KH}_{2} \mathrm{PO}_{4}, 0.5 \mathrm{~g} \mathrm{NaCl}, 1 \mathrm{~g}$ glutamate, $10 \mathrm{~g}$ mannitol, $1 \mathrm{mg}$ biotin, $27.8 \mathrm{mg} \mathrm{CaCl} 2$ and $246 \mathrm{mg} \mathrm{MgSO}_{4}$ per litre) containing $50 \mu \mathrm{g}$ gentamycin per $\mathrm{ml}$, and in $\mathrm{AB}$ medium $[44,55]$.

Extraction and detection of AHLs. AHL molecules were extracted following the technique described in our previous studies [56,57]. Briefly, $20 \mathrm{~mL}$ cultures were grown until the early stationary phase (optical density of approximately 2.8 at $600 \mathrm{~nm}$ ) and then extracted twice with equal volumes of dichloromethane. The extracts were dried and suspended in $40 \mu \mathrm{L}$ of $70 \% \mathrm{v} / \mathrm{v}$ methanol.

To detect AHLs, an overnight culture of one of the AHL indicator strains [Chromobacterium violaceum CV026 or Agrobacterium tumefaciens NTL4 (pZLR4)] was diluted 1:100 in 5ml of the corresponding medium and poured onto $\mathrm{LB} / \mathrm{MC}$ and $\mathrm{AB}$ supplemented with $80 \mu \mathrm{g}$ of 5-bromo-4chloro-3-indolyl- $\beta$-D-galactopyranoside (X-Gal) per $\mathrm{ml}$ agar plates. Once the plates were dry, paper disks $5 \mathrm{~mm}$ in diameter were placed onto them and the AHL samples applied. The assay plates were incubated overnight at $32{ }^{\circ} \mathrm{C}$ to allow the indicator organisms to grow and surround the paper disks with either purple or blue haloes.

Thin-layer chromatography analysis of AHLs. To characterize the AHLs, the samples were subjected to analytical and preparative thin-layer chromatography (TLC). AHL samples and standards were spotted onto a TLC plate and developed with 70\% v/v methanol in water. The plate was air-dried and overlaid with top agar containing the $A$. tumefaciens NTL4 (pZLR4) indicator strain before being incubated at $32{ }^{\circ} \mathrm{C}$. For the $A$. tumefaciens NTL4 (pZLR4) overlay, a 6-8 h culture in MGM medium was mixed with an equal volume of fresh medium, 1.5\% w/v Bacto Agar and $80 \mu \mathrm{g}$ of X-Gal per mL [26].

The standard AHLs used were: $N$-( $\beta$-ketocaproyl)-dl-homoserine lactone (3-oxo- $\mathrm{C}_{6}$-HSL), $N$-hexanoyl-dl-homoserine lactone $\left(\mathrm{C}_{6}\right.$-HSL), $N$-octanoyl-dl-homoserine lactone $\left(\mathrm{C}_{8}\right.$-HSL $)$ and $N$-decanoyl-dl-homoserine lactone $\left(\mathrm{C}_{10}\right.$-HSL) $\left(\right.$ Sigma $\left.^{\circledR}\right)$.

Chromosomal DNA extraction, autoinducer synthase gene amplification and sequencing. Chromosomal DNA was isolated and purified according to Marmur's protocol [58], modified by Martín-Platero and co-workers [59]. The purified DNA was dissolved in $50 \mu \mathrm{L}$ doubly distilled water 
and checked by agarose gel electrophoresis [60] An internal segment of the autoinducer synthase gene was amplified from approximately $100 \mathrm{ng}$ of chromosomal DNA by using the primers luxI-F: 5'-GGGAGATATATACTGTAA-3' and luxI-R: 5'-TGAGGTATTATTCTGCAA-3'. These primers were designed to target a highly conserved region of the hanI autoinducer synthase gene of Halomonas anticariensis $\mathrm{FP} 35^{\mathrm{T}}$. The hanI gene is about $645 \mathrm{bp}$ and the primer pair amplified approximately 386 $\mathrm{bp}$ of the conserved active site of the enzyme which contains the three conserved amino acids Arg71 (R71), Glu101 (E101) and Arg104 (R104) [27]. PCR entailed 30 cycles of $30 \mathrm{~s}$ at $95{ }^{\circ} \mathrm{C}, 30 \mathrm{~s}$ at $50{ }^{\circ} \mathrm{C}$ and $30 \mathrm{~s}$ at $72{ }^{\circ} \mathrm{C}$. The annealing temperature was determined by PCR with a temperature gradient from $40{ }^{\circ} \mathrm{C}$ to $60{ }^{\circ} \mathrm{C}$. All of the PCRs were run in a T100 ${ }^{\mathrm{TM}}$ thermal cycler (Bio-Rad).

The PCR fragments were purified and sequenced with luxI-F or luxI-R primers using a BigDye Terminator Cycle Sequencing Kit in an ABI 3100 DNA sequencer (Applied Biosystems). The DNA sequences thus obtained were analysed using a BLAST search of the GenBank database [61] to align homologous regions of autoinducer synthase gene sequences from different isolates.

Phylogenetic analysis. A phylogenetic tree was constructed using version 4 of the MEGA (Molecular Evolutionary Genetics Analysis) software [62] after multiple alignments of the data by CLUSTALW [63] and the alignments were checked manually. Distances and clustering were determined according to the neighbour-joining method and bootstrap values were measured on the basis of 1,000 replications.

Nucleotide sequence accession number. The autoinducer synthase DNA sequences reported here have been deposited in the GenBank database under accession numbers from KC 244227 to $\mathrm{KC} 244255$.

\section{Conclusions}

Screening for AHL signal molecules in 43 species belonging to the Halomonadaceae family revealed that the AHL-QS system is widespread within this group of bacteria. We did however find diversity within the AHL-profile signalling molecules produced by the different genera, and even between the molecules produced by different species from the same genus. Such variety would seem to be consistent with the ecological, physiological, metabolic and taxonomic diversity among them. The role of QS signalling in these extremophilic microorganisms remains to be elucidated and further work needs to be done to explore this bacterial cell-cell communication process in the multispecies communities.

\section{Acknowledgments}

This research was supported by grants from the Spanish Ministry of Education and Science (CGL2008-02399/BOS; AGL2009-07656), the Andalucian Government Council for Education, Science and Business (P07-CVI-03150) and from the Andalucian Research Project. Ali Tahrioui was supported by a postgraduate grant from the Junta de Andalucía. We thank our colleague Rafael de la Haba of the University of Seville for providing some of the type strains used in this work and J. Trout for revising and editing our English text. 


\section{References}

1. Brock, T. Halophilic-blue-green algae. Arch. Microbiol. 1976, 107, 109-111.

2. Rodríguez-Valera, F. Characteristics and microbial ecology of hypersaline environments. In Halophilic Bacteria; Rodríguez-Valera, F., Ed.; CRC Press: Boca Raton, Florida, USA, 1988; Volume 1, pp. 3-30.

3. Cifuentes, A.; Antón, J.; De Wit, R.; Rodríguez-Valera, F. Diversity of Bacteria and Archaea in sulphate-reducing enrichment cultures inoculated from serial dilution of Zostera noltii rhizosphere samples. Environ. Microbiol. 2003, 5, 754-764.

4. González-Toril, E.; Llobet-Brossa, E.; Casamayor, E.O.; Amann, R.; Amils, R. Microbial ecology of an extreme acidic environment, the Tinto River. Appl. Environ. Microbiol. 2003, 69, 4853-4865.

5. Horikoshi, K.; Grant, W.D. Extremophiles: Microbial Life in Extreme Environments; Wiley-Liss: New York, USA, 1998.

6. Ventosa, A. Unusual micro-organisms from unusual habitats: Hypersaline environments. In Prokaryotic Diversity: Mechanisms and Significance; Logan, N.A., Lappin-Scott, H.M., Oyston, P.C.F., Eds.; Cambridge University Press: New York, USA, 2006; pp. 223-253.

7. Franzmann, P.D.; Wehmeyer, U.; Stackebrandt, E. Halomonadaceae fam. nov., a new family of the Class Proteobacteria to accommodate the genera Halomonas and Deleya. Syst. Appl. Microbiol. 1988, 11, 16-19.

8. Ventosa, A.; Nieto, J.J.; Oren, A. Biology of moderately halophilic aerobic bacteria. Microbiol. Mol. Biol. Rev. 1998, 62, 504-544.

9. Euzéby, J.P. List of Prokaryotic Names with Standing in Nomenclature. 2012, Available online: http://www.bacterio.cict.fr/ (accessed on 15 November 2012).

10. Kushner, D.; Kamekura, M. Physiology of halophilic eubacteria. Halophilic Bacteria; Rodríguez-Valera, F. Ed.; CRC Press: Boca Raton, Florida, USA, 1988; Volume 1, pp. 87-103.

11. Ventosa, A.; Mellado, E.; Sánchez-Porro, C.; Márquez, M.C. Halophilic and halotolerant micro-organisms from soils. In Microbiology of Extreme Soils; Dion, P., Nautiyal, C., Eds.; Springer-Verlag: Heidelberg, Germany, 2008; Volume 13, pp. 87-115.

12. Nieto, J.J.; Carmen, V.M. Synthesis of osmoprotectants by moderately halophilic bacteria: Genetic and applied aspects. In Recent Research and Development in Endocrinology; Transworld Research Network: Kerala, India, 2002; pp. 403-418.

13. De la Haba, R.R.; Sánchez-Porro, C.; Márquez, M.C.; Ventosa, A. Taxonomy of Halophiles. In Extremophiles Handbook; Horikoshi, K., Ed.; Springer: New York, NY, USA, 2011.

14. Oren, A. Industrial and environmental applications of halophilic microorganisms. Environ. Technol. 2010, 31, 825-834.

15. Kaye, J.Z.; Baross, J.A. High incidence of halotolerant bacteria in Pacific hydrothermal-vent and pelagic environments. FEMS Microbiol. Ecol. 2000, 32, 249-260.

16. Oueriaghli, N.; González-Domenech, C.M.; Martínez-Checa, F.; Muyzer, M.; Quesada, E.; Béjar, V. Estudio molecular de la diversidad del género Halomonas en Rambla Salada mediante DGGE, CARD-FISH y análisis multivariable. Presented at the XIV Reunión del Grupo de Taxonomía Filogenia y Biodiversidad Microbiana (SEM), Granada, España, 10-11 May 2012. 
17. Parker, C.T.; Sperandio, V. Cell-to-cell signalling during pathogenesis. Cell. Microbiol.2009, 11, 363-369.

18. Williams, P. Quorum sensing, communication and cross-kingdom signalling in the bacterial world. Microbiology 2007, 153, 3923-3938.

19. Jung, K.; Fried, L.; Behr, S.; Heermann, R. Histidine kinases and response regulators in networks. Curr. Opin. Microbiol. 2012, 15, 118-124.

20. González, J.E.; Marketon, M.M. Quorum sensing in nitrogen-fixing rhizobia. Microbiol. Mol. Biol. Rev. 2003, 67, 574-592.

21. Whitehead, N.A.; Barnard, A.M.; Slater, H.; Simpson, N.J.; Salmond, G.P. Quorum-sensing in Gram-negative bacteria. FEMS Microbiol. Rev. 2001, 25, 365-404.

22. Eberhard, A.; Longin, T.; Widrig, C.A.; Stranick, S.J. Synthesis of the lux gene autoinducer in Vibrio fischeri is positively autoregulated. Arch. Microbiol. 1991, 155, 294-297.

23. Fuqua, W.C.; Winans, S.C.; Greenberg, E.P. Quorum sensing in bacteria: the LuxR-LuxI family of cell density-responsive transcriptional regulators. J. Bacteriol. 1994, 176, 269-275.

24. Swift, S.; Williams, P.; Stewart, G.S.A.B. $N$-acyl homoserine lactones and quorum sensing in proteobacteria. In Cell-Cell Signaling in Bacteria.; Dunny, G.M., Winans, S.C., Eds.; American Society of Microbiology Press: Washington, DC, USA, 1999; pp. 291-314.

25. Case, R.J.; Labbate, M.; Kjelleberg, S. AHL-driven quorum-sensing circuits: their frequency and function among the Proteobacteria. The ISME J. 2008, 2, 345-349.

26. Llamas, I.; Quesada, E.; Martínez-Cánovas, M.J.; Gronquist, M.; Eberhard, A.; González, J.E. Quorum sensing in halophilic bacteria: Detection of $N$-acyl-homoserine lactones in the exopolysaccharide-producing species of Halomonas. Extremophiles. 2005, 9, 333-341.

27. Tahrioui, A.; Quesada, E.; Llamas, I. The hanR/hanI quorum-sensing system of Halomonas anticariensis, a moderately halophilic bacterium. Microbiology 2011, 157, 3378-3387.

28. Tahrioui, A.; Quesada, E.; Llamas, I. Genetic and phenotypic analysis of the GacS/GacA system in the moderate halophile Halomonas anticariensis. Microbiology 2013, 159, 461-473.

29. Amjres, H.; Béjar, V.; Quesada, E.; Abrini, J.; Llamas, I. Halomonas rifensis sp. nov., an exopolysaccharide-producing, halophilic bacterium isolated from a solar saltern. Int. J. Syst. Evol. Microbiol. 2011, 61, 2600-2605.

30. Dobson, S.J.; Franzmann, P.D. Unification of the genera Deleya (Baumann et al. 1983), Halomonas (Vreeland et al. 1980), and Halovibrio (Fendrich 1988) and the Species Paracoccus halodenitrificans (Robinson and Gibbons 1952) into a single genus, Halomonas, and placement of the Genus Zymobacter in the family Halomonadaceae. Int. J. Syst. Bacteriol. 1996, 46, 550-558.

31. González-Domenech, C.M.; Béjar, V.; Martínez-Checa, F.; Quesada, E. Halomonas nitroreducens sp. nov., a novel nitrate- and nitrite-reducing species. Int. J. Syst. Evol. Microbiol. 2008, 58, 872-876.

32. González-Domenech, C.M.; Martínez-Checa, F.; Quesada, E.; Béjar, V. Halomonas cerina sp. nov., a moderately halophilic, denitrifying, exopolysaccharide-producing bacterium. Int. J. Syst. Evol. Microbiol. 2008, 58, 803-809.

33. González-Domenech, C.M.; Martínez-Checa, F.; Quesada, E.; Béjar, V. Halomonas fontilapidosi sp. nov., a moderately halophilic, denitrifying bacterium. Int. J. Syst. Evol. Microbiol. 2009, 59, 1290-1296. 
34. Llamas, I.; Béjar, V.; Martínez-Checa, F.; Martínez-Cánovas, M.J.; Molina, I.; Quesada, E. Halomonas stenophila sp. nov., a halophilic bacterium that produces sulphate exopolysaccharides with biological activity. Int. J. Syst. Evol. Microbiol. 2011, 61, 2508-2514.

35. Luque, R.; Béjar, V.; Quesada, E.; Martínez-Checa, F.; Llamas, I. Halomonas ramblicola sp. nov., a moderately halophilic bacterium from Rambla Salada, a Mediterranean hypersaline rambla in south-east Spain. Int. J. Syst. Evol. Microbiol. 2012, 62, 2903-2909.

36. Martínez-Cánovas, M.J.; Béjar, V.; Martínez-Checa, F.; Quesada, E. Halomonas anticariensis sp. nov., from Fuente de Piedra, a saline-wetland, wildfowl reserve in Málaga, Southern Spain. Int. J. Syst. Evol. Microbiol. 2004, 54, 1329-1332.

37. Martínez-Cánovas, M.J.; Quesada, E.; Llamas, I.; Béjar, V. Halomonas ventosae sp. nov., a moderately halophilic, denitrifying, exopolysaccharide-producing bacterium. Int. J. Syst. Evol. Microbiol. 2004, 54, 733-737.

38. Quesada, E.; Valderrama, M.J.; Bejar, V.; Ventosa, A.; Gutierrez, M.C.; Ruiz-Berraquero, F.; Ramos-Cormenzana, A. Volcaniella eurihalina gen. nov., sp. nov., a moderately halophilic nonmotile Gram-negative rod. Int. J. Syst. Bacteriol. 1990, 40, 261-267.

39. Valderrama, M.J.; Quesada, E.; Béjar, V.; Ventosa, A.; Gutierrez, M.C.; Ruiz-Berraquero, F.; Ramos-Cormenzana, A. Deleya salina sp. nov., a moderately halophilic Gram-negative bacterium. Int. J. Syst. Bacteriol. 1991, 41, 377-384.

40. Martínez-Checa, F.; Béjar, V.; Martínez-Cánovas, M.J.; Llamas, I.; Quesada, E. Halomonas almeriensis sp. nov., a moderately halophilic, exopolysaccharide-producing bacterium from Cabo de Gata, Almería, south-east Spain. Int. J. Syst. Evol. Microbiol. 2005, 55, 2007-2011.

41. Mellado, E.; Moore, E.R.B.; Nieto, J.J.; Ventosa, A. Phylogenetic inferences and taxonomic consequences of $16 \mathrm{~S}$ ribosomal DNA sequence comparison of Chromohalobacter marismortui, Volcaniella eurihalina, and Deleya salina and reclassification of $V$. eurihalina as Halomonas eurihalina comb. nov. Int. J. Syst.Bacteriol. 1995, 45, 712-716.

42. Steindler, L.; Venturi, V. Detection of quorum-sensing $N$-acyl homoserine lactone signal molecules by bacterial biosensors. FEMS Microbiol. Lett. 2007, 266, 1-9.

43. McClean, K.H.; Winson, M.K.; Fish, L.; Taylor, A.; Chhabra, S.R.; Cámara, M.; Daykin, M.; Lamb, J.H.; Swift, S.; Bycroft, B.W.; et al. Quorum sensing and Chromobacterium violaceum: Exploitation of violacein production and inhibition for the detection of $\mathrm{N}$-acyl homoserine lactones. Microbiology 1997, 143, 3703-3711.

44. Shaw, P.D.; Ping, G.; Daly, S.L.; Cha, C.; Cronan, J.E., Jr.; Rinehart, K.L.; Farrand, S.K. Detecting and characterizing $N$-acyl-homoserine lactone signal molecules by thin-layer chromatography. Proc. Natl. Acad. Sci. USA 1997, 94, 6036-6041.

45. García-Aljaro, C.; Eberl, L.; Riedel, K.; Blanch, A. Detection of quorum-sensing-related molecules in Vibrio scophthalmi. BMC Microbiol. 2008, 8, 138.

46. Yang, Q.; Han, Y.; Zhang, X.H. Detection of quorum sensing signal molecules in the family Vibrionaceae. J. Appl. Microbiol. 2011, 110, 1438-1448.

47. Parsek, M.R.; Greenberg, E.P. Acyl-homoserine lactone quorum sensing in Gram-negative bacteria: A signaling mechanism involved in associations with higher organisms. Proc. Natl. Acad. Sci. USA 2000, 97, 8789-8793. 
48. Parsek, M.R.; Schaefer, A.L.; Greenberg, E.P. Analysis of random and site-directed mutations in rhlI, a Pseudomonas aeruginosa gene encoding an acylhomoserine lactone synthase. Mol. Microbiol. 1997, 26, 301-310.

49. Hanzelka, B.L.; Parsek, M.R.; Val, D.L.; Dunlap, P.V.; Cronan, J.E.; Greenberg, E.P. Acylhomoserine lactone synthase activity of the Vibrio fischeri AinS protein. J. Bacteriol. 1999, $181,5766-5770$.

50. Milton, D.L.; Chalker, V.J.; Kirke, D.; Hardman, A.; Cámara, M.; Williams, P. The LuxM Homologue VanM from Vibrio anguillarum directs the synthesis of $N$-(3-hydroxyhexanoyl)homoserine lactone and $N$-hexanoyl-homoserine lactone. J. Bacteriol. 2001, 183, 3537-3547.

51. Laue, B.E.; Jiang, Y.; Chhabra, S.R.; Jacob, S.; Stewart, G.S.A.B.; Hardman, A.; Downie, J.A.; O'Gara, F.; Williams, P. The biocontrol strain Pseudomonas fluorescens F113 produces the Rhizobium small bacteriocin, N-(3-hydroxy-7-cis-tetradecenoyl) homoserine lactone, via HdtS, a putative novel $\mathrm{N}$-acylhomoserine lactone synthase. Microbiology 2000, 146, 2469-2480.

52. Haynes, W.C.; Wickerham, L.J.; Hesseltine, C.W. Maintenance of cultures of industrially important microorganisms. Appl. Microbiol. 1955, 3, 361-368.

53. Moraine, R.A.; Rogovin, P. Kinetics of polysaccharide B-1459 fermentation. Biotechnol. Bioeng. 1966, 8, 511-524.

54. Rodríguez-Valera, F.; Ruíz-Berraquero, F.; Ramos-Cormenzana, A. Characteristics of the heterotrophic bacterial populations in hypersaline environments of different salt concentrations. Microb. Ecol. 1981, 7, 235-243.

55. Cha, C.; Gao, P.; Chen, Y.-C.; Shaw, P.D.; Farrand, S.K. Production of acyl-Homoserine lactone quorum-sensing signals by Gram-negative plant-associated bacteria. Mol. Plant. Microbe In. 1998, 11, 1119-1129.

56. Marketon, M.M.; Gronquist, M.R.; Eberhard, A.; González, J.E. Characterization of the Sinorhizobium meliloti sinR/sinI locus and the production of novel $\mathrm{N}$-acyl homoserine lactones. J. Bacteriol. 2002, 184, 5686-5695.

57. Llamas, I.; Keshavan, N.; González, J.E. Use of Sinorhizobium meliloti as an indicator for specific detection of longchain $\mathrm{N}$-acyl homoserine lactones. Appl. Environ. Microbiol. 2004, 70, 3715-3723.

58. Marmur, J. A procedure for the isolation of deoxyribonucleic acid from micro-organisms. J. Mol. Biol. 1961, 3, 208-218.

59. Martín-Platero, A.M.; Valdivia, E.; Maqueda, M.; Martínez-Bueno, M. Fast, convenient, and economical method for isolating genomic DNA from lactic acid bacteria using a modification of the protein "salting-out" procedure. Anal. Biochem. 2007, 366, 102-104.

60. Sambrook, J.; Russel, D.W., Molecular Cloning: A Laboratory Manual 3rd Ed.; Cold Spring Harbor Laboratory Press: New York, USA, 2001.

61. National Center for Biotechnology Information, N. Available online: http://www.ncbi.nlm.nih.gov/ (accessed on 15 November 2012).

62. Tamura, K.; Dudley, J.; Nei, M.; Kumar, S. MEGA4: Molecular Evolutionary Genetics Analysis (MEGA) Software Version 4.0. Mol.Biol. Evol. 2007, 24, 1596-1599. 
63. Thompson, J.D.; Gibson, T.J.; Plewniak, F.; Jeanmougin, F.; Higgins, D.G. The CLUSTAL_X windows interface: Flexible strategies for multiple sequence alignment aided by quality analysis tools. Nucleic Acids Res. 1997, 25, 4876-4882.

(C) 2013 by the authors; licensee MDPI, Basel, Switzerland. This article is an open access article distributed under the terms and conditions of the Creative Commons Attribution license (http://creativecommons.org/licenses/by/3.0/). 